\title{
The Relationship Between the Perception of Traditional Medicine Use and the Quality of Community Life in Pulungdowo Village, Tumpang Sub-District, Malang Regency
}

\author{
Anggi Restyana ${ }^{1}$, Khalimatus Nur \\ Eka Agustanti', Lisa Savitri ${ }^{2}$, Nur \\ Fahma Laili ${ }^{1}$ \\ ${ }^{1}$ Pharmacy Undergraduate \\ Program, Faculty of Social Health, \\ Kadiri University \\ ${ }^{2}$ Medical Laboratory Technology \\ Program, Kadiri University \\ Email: \\ anggi.restyana@unik-kediri.ac.id
}

Received: October 5, 2020

Accepted : November 27, 2020

Published : November 30, 2020

\begin{abstract}
Background Public interest in use of traditional medicines in Indonesia is high. Community in Pulungdowo is one of them. Use of traditional medicines can support the QoL community for their safety and benefits. Measurement of QoL was carried out using Short Form (SF-36). Purpose was to determine relationship between perception of the use of traditional medicine and QoL of the community in Pulungdowo. Methods used descriptive analytic method with quantitative approach using purposive sampling method. Retrieval of research data used questionnaires distributed to 100 respondents in Pulungdowo. Result perception of the use of traditional medicine obtained a total score of 29; mean $=25.65$ and $\mathrm{SD}=4.89$. On QoL of community showed results of average value of each sub-variable QoL that is more than 50. Analysis test of relationship between perception of the use of traditional medicines with QoL, results obtained with a sig 0,000. Conclusion respondents perceptions on the use of traditional medicines was good which meant that respondents could receive and process information well about the use of traditional medicines. In addition, QoL of community after using traditional medicines was also said to be good. Results of the analysis of relationship between perception of the use of traditional medicine and QoL of Pulungdowo showed that there was a relationship between perception of the use of traditional medicine and QoL community. It is needed to improve health promotion programs such as counselling about introduction of traditional medicine types regarding to large number of people only know herbal medicines.
\end{abstract}

Keywords: Traditional medicine, quality of life, sf-36, community

Copyright $(0) 2020$ IIK STRADA Indonesia All right reserved.

This is an open-acces article distributed under the terms of the Creative Commons Attribution-ShareAlike 4.0 International License.

\section{BACKGROUND}

Medicine is an important element in effort to improve our health; therefore in order to be beneficial, sufficient numbers and types of medicines based on needs are needed. One of the medicines needed besides synthetic medicines is traditional medicine which is obtained from nature. Traditional medicine is also an important part in effort to maintain and restore public health. Almost 
all users of traditional medicines assume that besides being cheap, traditional medicines have less side effects than synthetic medicines. The campaign to return to nature or known as "back to nature" becomes an important topic of conversation along with the increasing benefits of using traditional medicines (Fitriyani, 2017).

Although traditional medicine is popular, most people have only limited knowledge of various types of traditional medicines and their benefits. Most people only know the first type of traditional medicine, namely ' Jamu' (Indonesian herbal medicine). Their benefits to maintain health and even treat diseases have been felt by many people who consume them. One of those is the community in Pulungdowo Village, Tumpang Sub-district, Malang Regency. It can be seen from the absence of health facilities such as pharmacies, clinics, and hospitals in Pulungdowo Village, which makes the community prefer traditional medicine as an alternative treatment (Hadi, 2019). When It is viewed from safety and benefits sides, the use of traditional medicines can support the quality of life of the community. Most people like to consume personalized traditional medicine such as turmeric, tamarind, cinnamon, ginger, honey to be used as immune system (antioxidants). One indicator of the usefulness of a therapy in relieving symptoms of a disease is quality of life. High quality of life will increase cure rate and reduce disease morbidity (Ridha, et al., 2014).

Based on data from Riskesdas (2010), almost half (49.53\%) of Indonesia's population aged 15 years and over, consume Jатu (Indonesian herbal medicine). About five percent (4.36\%) consume Јати (Indonesian herbal medicine) every day, while the rest $(45.17 \%)$ consume it occasionally. The proportion of types of Jатu that is chosen for consumption is drinking liquid (55.16\%); powder (43.99\%); and brewed Јати (20.43\%). While the smallest proportion is modern wrapped Jати in capsules / pills / tablets (11.58\%). Whereas in 2013 it was stated that of 294,692 households in Indonesia utilized traditional health services (yankestrad) and in the last one year $30.4 \%(89,753)$ (Riskesdas, 2013). Furthermore, there are two main challenges in the use of traditional medicines in Indonesia. First, consumers tend to assume that traditional medicines (herbs) are always safe. The next challenge is the permit of traditional medicine practice and the qualifications of traditional health practitioners (RI Ministry of Health, 2011).

The indicator of a successful treatment can be seen from the quality of life. If the quality of life of community is good, it can be said that the treatment is successful. A successful treatment is completely cure or relieve symptoms of the disease (temporary recovery). The measurement of quality of life can be carried out by using a generic quality of life instrument called the 36-item Short Form and Health Survey (SF-36). SF-36 is a survey questionnaire that measures 8 health criteria, namely physical function, limited role due to physical health, ill body, general health perception, vitality, social function, limited role due to emotional problems, and psychological health (Fatma, 2018). Based on the description above, the author is interested in conducting research with the title "Perception of Use of Traditional Medicines and Their Relationship to the Quality of Life of Communities in Pulungdowo Village, Tumpang Sub-district, Malang Regency".

\section{OBJECTIVES}

1. To determine the perception of the use of traditional medicines in Pulungdowo Village, Tumpang Sub-district, Malang Regency.

2. To find out the quality of life of the community in Pulungdowo Village, Tumpang Sub-district, Malang Regency after using traditional medicines.

3. To find out the relationship between the perception of the use of traditional medicines and the quality of life of the community in Pulungdowo Village, Tumpang Sub-district, Malang Regency.

\section{METHODS}

Research Location and Time 
This research was conducted in Pulungdowo Village, Tumpang Sub-district, Malang Regency. Data collection for the validity test and reliability test (survey) was conducted on 1-8 October 2019. The research data was collected from 1 - 31 December 2019.

\section{Population and Sample}

\section{A. Research Population}

The population in this study was the community of Pulungdowo Village, Tumpang Sub-district, Malang Regency of totalled 5,410 people based on the latest population data in July 2019.

\section{B. Research sample}

The sample in this study was a portion of the community of Pulungdowo Village, Tumpang Subdistrict, Malang Regency who met the inclusion criteria. Based on the formula, the number of respondents used as samples is:

$\mathrm{n}=\frac{5.410}{1+5.410(0,1)^{2}}$

$=98,185$ respondents rounded up to 100 respondents

The minimum numbers of samples to be taken and given questionnaires of 100 respondents.

\section{Research Instruments}

Questionnaires were used to obtain information from respondents about things that are known. The questionnaires contain questions and statements that are arranged and refer to the research problems and are divided into four parts. The first part contains the screening data of respondents. The second part contains the respondent's personal data. The third part contains statements about perceptions of using traditional medicines that refer to the questionnaires (Hapsari, 2011) and the questionnaires (Merdekawati, 2016) and the fourth section contains questions and statements about the quality of life of the respondents referring to the SF-36 questionnaire modified into Indonesian. Primary data were obtained directly from respondents by means of a survey using questionnaires.

\section{Workflow}

The study was conducted by collecting information directly from the community of Pulungdowo Village, Tumpang Sub-district, Malang Regency by using questionnaires. The stages of research are as follows.

\section{A. Preparation Stage}

a) Prepare a research proposal and test the validity and reliability of the questionnaire in Pulungdowo Village.

b) Present the proposal in a research proposal session.

c) Arrange a research permit letter after obtaining approval from the advisors.

d) Conducting research permission to the head of Pulungdowo Village, Tumpang Sub-district, Malang Regency.

\section{B. Implementation Stage}

a) Determine research samples.

b) Collecting data from Pulungdowo Village using questionnaires.

\section{Processing Stage}

a) Questionnaire I is screening data

b) Questionnaire II is the respondent's personal data, included gender, age, occupation, income, and questions about traditional medicines.

c) Questionnaire III is statements regarding the perception of using traditional medicines. 
In this questionnaire each statement provides four alternative answers, namely SS (strongly agree), S (agree), TS (disagree), STS (strongly disagree). For the assessment scale of each statement item starts from a score of four to one (Hapsari, 2011).

Table 1. Score statements on a Likert scale (Hapsari, 2011)

\begin{tabular}{cc}
\hline Answer & Score \\
\hline Strongly Agree & 4 \\
Agree & 3 \\
Disagree & 2 \\
Strongly disagree & 1 \\
\hline
\end{tabular}

d) Questionnaire IV is statements regarding the quality of life of community after using traditional medicines.

Score Transformation $=\frac{(\text { Obtained Score }- \text { lowest score })}{\text { Difference between highest and lowest score }} \times 100($ Melani, 2016)

The results of respondents' scores of data distribution are not normal, so to determine the quality of life, a median value of 50 is used. $1=$ lack of quality, $<50 ; 2=$ good quality, $\geq 50$ (Fatma, 2018).

\section{Data analysis}

To find out the relationship between the two variables, Rank Spearman statistical test was done with a significance level of 0.05 with SPSS 15 version 21 software to determine whether there was a relationship between the two variables, namely the independent variable and the dependent variable which are ordinal scales (Sugiyono, 2015). If $\mathrm{p}$ value $<\alpha 0,05$, then $\mathrm{H} 1$ is accepted. While $\mathrm{p}$ value $>\alpha$ 0.05 then $\mathrm{H} 1$ is rejected. As a guideline to provide interpretation, researchers used the following units of numbers:

Table 2. Correlation Coefficient Score according to Guilford (Arikunto, 2010).

\begin{tabular}{cc}
\hline Coefficient interval & Relationship Level \\
\hline $0,00-0,019$ & very low \\
$0,20-0,339$ & low \\
$0,40-0,599$ & moderate \\
$0,60-0,799$ & strong \\
$0,80-1,000$ & very strong \\
\hline
\end{tabular}

\section{RESULTS}

This research was conducted in Pulungdowo Village, Tumpang Sub-district, Malang Regency for 2 months. The total sample was 100 respondents who used traditional medicines. Samples were taken by using purposive sampling technique. This research was conducted using an instrument in the form of questionnaires as a tool for collecting data and then the data were collected and processed to obtain result and it can be presented as follows:

\section{a. Demographic Data of Respondents}

Table 3. Demographic Data of Respondents

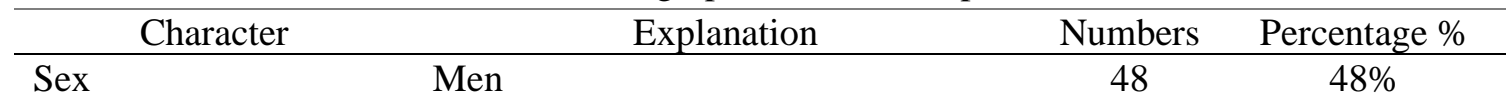




\begin{tabular}{|c|c|c|c|}
\hline & Women & 52 & $52 \%$ \\
\hline \multicolumn{2}{|r|}{ Total } & & $100 \%$ \\
\hline \multirow[t]{5}{*}{ Age } & $17-30$ years old & 26 & $26 \%$ \\
\hline & $31-40$ years old & 22 & $22 \%$ \\
\hline & $41-50$ years old & 28 & $28 \%$ \\
\hline & $51-60$ years old & 24 & $24 \%$ \\
\hline & Total & & $100 \%$ \\
\hline \multirow[t]{7}{*}{ Occupation } & entrepreneurs & 7 & $7 \%$ \\
\hline & Civil servants & 12 & $12 \%$ \\
\hline & Private employees & 37 & $37 \%$ \\
\hline & Students/ College students & 8 & $8 \%$ \\
\hline & Unemployed & 5 & $5 \%$ \\
\hline & Others & 31 & $31 \%$ \\
\hline & Total & & $100 \%$ \\
\hline \multirow[t]{5}{*}{ Income } & Not yet earning & 7 & $7 \%$ \\
\hline & $<\mathrm{Rp} 500.000,00$ & 12 & $12 \%$ \\
\hline & Rp500.000,00 - Rp1.000.000,00 & 37 & $37 \%$ \\
\hline & $>\mathrm{Rp} 1.000 .000,00$ & 8 & $8 \%$ \\
\hline & Total & & $100 \%$ \\
\hline \multirow{5}{*}{$\begin{array}{l}\text { the source of } \\
\text { information about } \\
\text { traditional medicines }\end{array}$} & family & 84 & $84 \%$ \\
\hline & friend & 3 & $3 \%$ \\
\hline & Medical practitioners & 6 & $6 \%$ \\
\hline & Mass Media & 7 & $7 \%$ \\
\hline & Others & 0 & $0 \%$ \\
\hline \multicolumn{2}{|r|}{ Total } & & $100 \%$ \\
\hline Character & Explanation & Numbers & Percentage $\%$ \\
\hline The length of using & $<1$ year & 4 & $4 \%$ \\
\hline traditional medicines & $1-5$ years & 5 & $5 \%$ \\
\hline & $>5$ years & 91 & $91 \%$ \\
\hline \multicolumn{2}{|r|}{ Total } & & $100 \%$ \\
\hline \multirow{4}{*}{$\begin{array}{l}\text { Frequency of using } \\
\text { traditional medicines in } \\
\text { a week }\end{array}$} & 1 time & 48 & $48 \%$ \\
\hline & $2-5$ times & 47 & $47 \%$ \\
\hline & $>5$ times & 5 & $5 \%$ \\
\hline & Total & & $100 \%$ \\
\hline \multirow{4}{*}{$\begin{array}{l}\text { Types of traditional } \\
\text { medicines used }\end{array}$} & Јати & 79 & $79 \%$ \\
\hline & Standardized herbal medicine & 21 & $21 \%$ \\
\hline & fitofarmaka (phytomedicines). & 0 & $0 \%$ \\
\hline & Total & & $100 \%$ \\
\hline \multirow{4}{*}{$\begin{array}{l}\text { The results of using } \\
\text { traditional medicines }\end{array}$} & completely recovered & 7 & $7 \%$ \\
\hline & temporary recovered & 93 & $93 \%$ \\
\hline & get worse & 0 & $0 \%$ \\
\hline & no benefits & 0 & $0 \%$ \\
\hline \multicolumn{3}{|c|}{ Total } & $100 \%$ \\
\hline
\end{tabular}

\section{b. Perception of Using Traditional Medicines}

Characteristics of respondents based on perceptions of respondents using traditional medicines obtained data as explained in the following table.

Table 4. Perception of using Traditional Medicines

\begin{tabular}{lccc}
\hline \multirow{2}{*}{ Statements } & \multicolumn{2}{c}{ Percentage } & \multirow{2}{*}{ tendency } \\
\cline { 2 - 3 } & $\mathbf{S S}+\mathbf{S}$ & TS + STS & \\
\hline Traditional medicine is a mixture of natural & $85 \%$ & $15 \%$ & Agree \\
$\begin{array}{l}\text { ingredients derived from plants, animals, } \\
\text { minerals, galenika, or a mixture of these }\end{array}$ & & & \\
minn & & & \\
& & &
\end{tabular}




\begin{tabular}{|c|c|c|c|}
\hline $\begin{array}{l}\text { Traditional medicines are classified into } 3 \\
\text { groups namely Jamu, Standardized Herbal } \\
\text { Medicine (OHT), and fitofarmaka } \\
\text { (phytomedicines). }\end{array}$ & $83 \%$ & $17 \%$ & Agree \\
\hline $\begin{array}{l}\text { Traditional medicine are only available in liquid } \\
\text { drinking or steeping form. }\end{array}$ & $47 \%$ & $53 \%$ & Disagree \\
\hline Traditional medicine can be taken every day. & $36 \%$ & $64 \%$ & Disagree \\
\hline $\begin{array}{l}\text { All traditional medicines are safe to take at any } \\
\text { time. }\end{array}$ & $48 \%$ & $52 \%$ & Disagree \\
\hline $\begin{array}{l}\text { The use of traditional medicine must follow the } \\
\text { dosage and directions. }\end{array}$ & $80 \%$ & $20 \%$ & Agree \\
\hline $\begin{array}{l}\text { The long term use of traditional medicine may } \\
\text { endanger health. }\end{array}$ & $67 \%$ & $33 \%$ & Agree \\
\hline $\begin{array}{l}\text { The effects of traditional medicine on the body } \\
\text { occur quickly. }\end{array}$ & $31 \%$ & $69 \%$ & Disagree \\
\hline $\begin{array}{l}\text { Traditional medicine can cure more than one } \\
\text { disease. }\end{array}$ & $22 \%$ & $78 \%$ & Disagree \\
\hline
\end{tabular}

\section{c. Quality of Life}

Characteristics of respondents based on quality of life for respondents using traditional medicine, the data obtained is explained in the following table.

Table 5. Quality of Life SF-36

\begin{tabular}{ll}
\hline \multicolumn{1}{c}{ Score of each Sub Variable (0-100) } & Average \\
\hline Physical functions & 99 \\
Physical roles & 100 \\
Emotion roles & 99 \\
Vitality & 81,13 \\
Mental health & 83,4 \\
Social Functions & 90 \\
Pain & 100 \\
General Health & 68,05 \\
\hline
\end{tabular}

\section{d. Data Analysis}

Data analysis is to see whether or not there is a relationship between the perception of the use of traditional medicines and the quality of life in the community in Pulungdowo Village, Tumpang Subdistrict, Malang Regency, the obtained data is explained in the following table.

Table 6. Spearman Rank Correlation Data Analysis

\begin{tabular}{ccc}
\hline Correlation & $\begin{array}{c}\text { Spearman Rank } \\
\text { Correlation Coefficient } \\
\text { Correlation (r) }\end{array}$ & Signification Value \\
\hline $\begin{array}{c}\text { Perception of the use of } \\
\text { traditional medicines and the } \\
\text { quality of life of the people }\end{array}$ & 0,748 & 0,000 \\
\hline
\end{tabular}

\section{DISCUSSION}

\section{a. Demographic Data of Respondents}

Based on research data (table 3) shows that the majority of respondents are women with a percentage of 52\%. According to Merdekawati (2016), the largest percentage of traditional medicines 
users is females. Likewise with the research of Supardi, et al (2010), Females take the largest proportion of characteristics who choose home treatment. According to Oktarlina, et al (2018), the largest percentage who use traditional medicines are women. This is caused by more female respondents are at home than males. Women are also considered more concerned about health than men and tend to have better knowledge about treatment. In the characteristics of respondents based on the most age groups using traditional medicines was the age range of 41-50 years with a percentage of $28 \%$. On the characteristics of respondents based on the most age groups using traditional medicines was the age range of $41-50$ years with a percentage of $28 \%$. The result of this study indicated that people suffer degenerative disease at this age so they tend to have treatment using traditional medicines (Merdekawati, 2016). On the characteristics of respondents based on work, the most results worked as private employees with a percentage of $37 \%$. Occupation will influence the decision process and consumption patterns of a person because occupation affects income. Generally, private employees have enough income to meet the consumption needs of Jamu routinely (Hapsari, 2011). On the characteristics of respondents based on income each month, the most results were those with income of Rp. 500,000.00 - Rp1,000,000.00 with a percentage of 37\%. In the research of Andriati et al (2016), income less than Rp1,000,000.00 has a high interest to use traditional medicines because they tend to consume them as an alternative way rather than to consume of modern medicines.

For the question about the source of people be familiar with traditional medicines, the most results came from families with percentage of $84 \%$. This result indicated that people be familiar with traditional medicine hereditary. According to Maryani, et al., (2016) families, friends, neighbors are the most effective media in finding information about traditional medicine treatment services. However, this also shows that people are lack of information about traditional medicine (Merdekawati, 2016). On the question regarding the length of using traditional medicines, the most results were over 5 years by $91 \%$. This result indicated that people began to change perceptions about traditional medicines that they are not as potent as modern medicines. People also begin to think that traditional medicine is safer than modern medicine because it rarely causes side effects (Hapsari, 2011). On questions about the frequency of using traditional medicines in a week, the results were 1 time for $48 \%, 2-5$ times for $47 \%$ and more than 5 times for $5 \%$. This result indicated that people consume traditional medicines only to maintain health and it means they consume traditional medicines only if it is necessary (Hapsari, 2011). According to Pujiyanto (2008) in his research, he mentioned that the frequency of taking traditional medicinal herbs varies between one-two-three times a day to once a week. The results of this study and previous studies reveal the same thing about the frequency of using various traditional medicines. On the question about the types of traditional medicines consumed, the result was Јати is the highest type of traditional medicine used for $79 \%$. This result indicated that people are more familiar with Јати as the first type of traditional medicine. Since ancient times it has become a habit or culture to use the values and properties of medicinal plants, where this habit can be found in several countries including China, Korea, and Japan (Nurrani, et al., 2015). In Asia, especially in Indonesia, the tradition of taking traditional medicines has long been developed in the form of Jати. This custom or tradition was first practiced by people of Kalimantan and was popularized by the Javanese community (Lis, et al., 2015). On questions regarding the result of the use of traditional medicine whether it is temporary cured or only relieve symptoms is $93 \%$. This result indicated that the community consumed traditional medicines to cure minor illnesses before they went to medical practitioners (Merdekawati, 2016). According Supriadi, et al (2010), the goals of self-medication are to improve health, treat mild pain and routinely treat chronic diseases after receiving treatment by doctors.

\section{b. Perception of Using Traditional Medicines}

Based on the results of the research which had been done, in table 4 regarding the perception of the use of traditional medicines, almost all positive statements (questions number 1,2,6,7,9) tend to 
be answered "agree" and negative statements (questions number $3,4,5,8$ ) tend to be answered "disagree", but only statement number 9 which should be answered "agree" but has a tendency to be answered "disagree" by respondents. In the statement of question number 1 regarding the definition of traditional medicine, people tend to answer 'agree'. The statement regarding the definition of traditional medicine is in accordance with the definition of traditional medicine in the Regulation of the Minister of Health of the Republic of Indonesia Number 6 of 2016. In the statement question number 2 regarding the types of traditional medicines, people tend to answer 'agree' which is suitable with BPOM Decree (2004) about the grouping and marking of traditional medicines in Indonesia that can be categorized into three category; herbal medicine, standardized herbal medicine and fitofarmaka (phytomedicines). In the statement question number 3 regarding the forms of traditional medicines, people tend to answer 'disagree'. This is suitable because traditional medicine forms are not only available in liquid drinking or steeping and according to BPOM Regulation (2019), there are many traditional medicine forms, including pills, dodol or jenang, capsules, tablets, patches, ointments, creams .

In the statement question 4 about whether traditional medicine can be taken every day, people tend to answer 'disagree'. This result indicated that people consume traditional medicines when it is necessary and indeed taking traditional medicines every day can also cause some side effects. For example, if you drink mangosteen juice every day for 12 months, you can experience severe lactic acidosis that is suspected derived from alpha-mangostin which can cause mitochondrial dysfunction (Minister of Health Regulation No.6, 2016). In addition, based on respondents, they consume traditional medicines every day usually for the prevention and treatment of disease (Veronika, 2016).

In statement number 5 regarding the safety of taking traditional medicines anytime, people tend to answer 'disagree'. For example, turmeric has been recognized for its benefits to reduce menstrual pain, but if it is consumed early in pregnancy, it can be dangerous and at risk of causing miscarriage. This shows that the correct time to consume traditional medicine can influence the effects that will be appeared (Merdekawati, 2016).

In statement number 6 regarding the accuracy of the dosage and the directions, people tend to answer 'agree'. This result is consistent with the statement of Merdekawati (2016) that medicinal plants still have a dose that must be followed. This statement dismissed the public's assumption that traditional medicine is not always safer than modern medicine. The right dose makes it a medicine, whereas overdose can make it toxic. This is also in accordance with the statement of Sumayyah, et al. (2017) that many people assume that medicinal plants can be consumed carelessly without the right dosage. Medicinal plants cannot be consumed freely. The measurement and dosage must still follow the provisions. This does not eliminate the possibility that medicinal plants have side effects.

In the statement number 7 regarding the long-term use that can endanger health, people tend to answer agree. For examples the long term consumption of bitter gourd, whether in the form of juice, raw vegetables, or cooked vegetables, can kill sperm, trigger impotence, damage hormones in men, and even potentially damage the liver (Sari, 2006). Another example is a long term use of jamu sari rapet since unmarried to married for a bit infertile women can cause difficulties in obtaining offspring because there is a possibility to shrink the size of the uterus (uterus) (Ningsih, 2016).

In the statement number 8 about the quick effects of traditional medicines, people tend to answer 'disagree'. Potions or concoctions or formulas of traditional medicines are constructive so to achieve optimal results or recovery, traditional medicines need to be consumed routinely and in longer time compared to modern or synthetic medicine (Parwata, 2016). It also goes with the statement of Ningsih (2016), that the weak and slow pharmacological effects of traditional medicines are caused by low levels of active compounds in natural medicinal substances and the complexity of ballast substances commonly found in plants, this is also one of the weakness of traditional medicine. 
In statement number 9 about whether traditional medicines can cure more than one disease, people tend to answer disagree. This result is unexpected because the active substances in medicinal plants are generally in the form of secondary metabolites, whereas one plant can produce several secondary metabolites that enable the plants to have more than one pharmacological effect (Merdekawati, 2016).

To find out how the perception of using traditional medicines in the Pulungdowo Village, Tumpang Sub-district, Malang Regency, researchers looked for the frequency distribution of the total answers of each respondent. The highest frequency was a total score of $29(x=29)$, then through calculations the mean $=25.65$ and $\mathrm{SD}=4.89$ were obtained. The calculation results concluded that respondents' perceptions about the use of traditional medicines were good ( $x>28.11$ and $x<32.99)$, based on the calculation results (Mean $+0.5 \mathrm{SD}<\mathrm{x}<\mathrm{Mean}+1.5 \mathrm{SD}$ ), it means that respondents could accept and process information well with the use of traditional medicines (Hapsari, 2011).

\section{c. Quality of life}

Based on table 5 regarding the quality of life of people after consuming traditional medicine, it can be said to be good. This can be seen from the results of the average value of each sub-variable of quality of life that is more than 50. This result is in accordance with the research of Fatma (2018) which stated that quality of life can be said to be good if it produces a value of $\geq 50$.

\section{d. Data analysis}

Based on the result of the relationship between the perception of the use of traditional medicine and the quality of life of the people in Pulungdowo Village, Tumpang Sub-district, Malang Regency in table VI, it showed that there is a relationship between the perception of the use of traditional medicines and the quality of life of the community. The correlation coefficient ( $r$ ) obtained from processing research data was 0.748 with a significance value of 0.000 . If the sig value $<0.05$, it indicates that there is a relationship between the perception of the use of traditional medicine and the quality of life of the community. The strength of the correlation between the two variables was relatively strong with the tendency to be positive correlation (Arikunto, 2010). Correlation coefficient which has a positive value means that the two variables have a linear relationship or directly proportional, it means that if the perception of the use of traditional medicine is high, then the value of the quality of life of the community is also high (Hapsari, 2011).

\section{CONCLUSIONS}

The conclusions of this research are as follows.

1. The perception of the use of traditional medicines in Pulungdowo Village, Tumpang sub-district, Malang Regency was good. It is as shown by the highest frequency results, 29.

2. The quality of life of the community of Pulungdowo Village, Tumpang Subdistrict, Malang Regency after using traditional medicines was good as indicated by the results of each subvariable of more than 50 .

3. There was a relationship between the perception of the use of traditional medicines and the quality of life of people who use traditional medicines in Pulungdowo Village, Tumpang subdistrict, Malang Regency, which is indicated by the relationship analysis test producing a significance value of 0,000 .

\section{ACKNOWLEDGMENTS}

Acknowledgments to the Head of Malang Regency's National Unity and Politics Agency (BAKESBANGPOL), Head of Tumpang Subdistrict, Malang regency, Head of Pulungdowo Village, Tumpang Subdistrict, Malang Regency, the respondents and all those who have helped with this research. 


\section{REFERENCES}

Andriati dan Wahjudi, R.M. (2016). "Tingkat Penerimaan Penggunaan Jamu sebagai Alternatif Penggunaan Obat Modern pada Masyarakat Ekonomi Rendah-Menengah dan Atas." Surabaya: Universitas Airlangga

Arikunto, S. (2010). “Prosedur Penelitian Suatu Pendekatan Praktik.” Jakarta: Rineka Cipta.

Badan Pengawas Obat dan Makanan. (2019). "Persyaratan Keamanan dan Mutu Obat Tradisional.” Jakarta: BPOM RI

Fatma, Titik R. (2018). "Hubungan Motivasi Keluarga Dengan Kualitas Hidup Pasien Yang Menjalani Hemodialisis.” (Skripsi). Jombang: Sekolah Tinggi Ilmu Kesehatan Insan Cendekia Medika Jombang

Fitriyani. (2017). “Eksistensi Jamu Tradisional di Tengah Masyarakat Desa Bragung Kecamatan Gulukguluk Kabupaten Sumenep dalam Pandangan Teori Tindakan Sosial Max Weber." (Skripsi). Surabaya: Universitas Islam Negeri Sunan Ampel Surabaya

Hadi, Akhmad K. (2019). "Kecamatan Tumpang dalam Angka.” Malang: Badan Pusat Statistik Kabupaten Malang. Kurnia Offshet.

Hapsari, Pascalia R. P. (2011). “Korelasi Antara Persepsi Bahaya Bahan Kimia Obat dan Perubahan Frekuensi Konsumsi Jamu Pegal Linu pada Konsumen Kios Jamu di Eks Kotip Cilacap.” (Skripsi). Yogyakarta: Universitas Sanata Dharma

Lis Nurrani, Supratman Tabba \& Hendra S. Mokodompit. (2015). "Local Wisdom in the Utilization of Medicine Plants by Community Around Aketajawe Lolobata National Park, North Maluku Province.” Jurnal Penelitian Sosial dan Ekonomi Kehutanan. 12(3): 163-175.

Maryani, H., Kristiana L., Lestari., W. (2016). "Faktor dalam Pengambilan Keputusan Pembelian Jamu Saintifik." Surabaya: Pusat Penelitian dan Pengembangan Humaniora dan Manajemen Kesehatan

Merdekawati, Rima B. (2016). “Gambaran Dan Tingkat Pengetahuan Penggunaan Obat Tradisional Sebagai Alternatif Pengobatan Pada Masyarakat Rw 005 Desa Sindurjan, Kecamatan Purworejo, Kabupaten Purworejo." (Skripsi). Yogyakarta: Universitas Muhammadiyah Yogyakarta

Ningsih, Indah Yulia. (2016). "Keamanan Jamu Tradisional.” Jember: Universitas Jember

Nurrani, L. dan Tabba, S. (2015). "Kearifan suku Togutil dalam konservasi Taman Nasional Aketajawe di wilayah hutan Tayawi Provinsi Maluku Utara." Prosiding Ekspose Hasil-Hasil Penelitian Balai Penelitian Kehutanan Manado. Manado: Balai Penelitian Kehutanan Manado.pp.227-244.

Oktarlina, Rasmi Z., Tarigan A., Carolia N., Utami E.R. (2018). "Hubungan Pengetahuan Keluarga dengan Penggunaan Obat Tradisional di Desa Nunggalrejo Kecamatan Penggur Kabupaten Lampung Tengah.” Lampung: Universitas Lampung

Parwata, I Made Oka Adi. (2016). “Diktat Obat Tradisional.” Bali: Universitas Udayana

Minister of health Regulation. (2016). "Formularium Obat Herbal Asli Indonesia." Jakarta

Pujiyanto. (2008). "Faktor Sosio Ekonomi yang Mempengaruhi Kepatuhan Minum Obat Antihipertensi.” Jurnal Kesehatan Masyarakat Nasional.

Ridha, P., Ardiyanto, D., Triyono, A. (2014). "Efek Ramuan Jamu Insomnia terhadap Kualitas Hidup Pasien Insomnia di Klinik "Hortus Medicus" Tawangmangu." Badan Litbangkes Kementrian Kesehatan RI

Riset Kesehatan Dasar. (2013). Badan Penelitian dan Pengembangan Kesehatan

Riset Kesehatan Dasar. (2010). Badan Penelitian dan Pengembangan Kesehatan

Sari, Lusia O, R, K. (2006). "Pemanfaatan Obat Tradisional dengan Pertimbangan Manfaat dan Keamanannya." Majalah Ilmu Kefarmasian Vol. III. No.1 ISSN : 1693-9883. (Online),

Sugiyono. (2015). “Metode Penelitian Kuantitatif, Kualitatif dan R\&D. ” Bandung: Penerbit CV Alfabeta.

Sumayyah, Shofiah dan Salsabila, N. (2017). "Obat Tradisional: Antara Khasiat dan Efek Sampingnya." Sumedang: Universitas Padjadjaran.

Supardi, S., Herman, M, J., dan Raharni. R. (2010). "Karakteristik Penduduk Sakit yang Memilih Pengobatan Rumah Tangga di Indonesia (Analisis Data Riskesdas 2007).” Buletin Penelitian Sistem Kesehatan. Vol 13.

Veronika. (2016). "Pola dan Motivasi Penggunaan Obat Tradisional untuk Pengobatan Mandiri di Kalangan Masyarakat Desa Dieng Kecamatan Kejajar Kabupaten Wonosobo Jawa Tengah.” (Skripsi). Yogyakarta: Universitas Sanata Dharma 